\section{ECONOMICS}

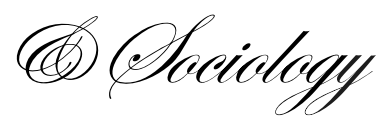

\author{
Maryna Martynenko \\ Faculty of Management and \\ Marketing \\ Kharkiv National University of \\ Economics \\ named after Simon Kuznets \\ Kharkiv, Ukraine \\ E-mail: \\ mrnmartynenko@gmail.com
}

Received: December, 2014

1st Revision: January, 2015

Accepted: April, 2015

DOI: 10.14254/2071-

789X.2015/8-1/7
Martynenko, M. (2015), Formation of organisational knowledge in Ukrainian enterprises on the basis of internal communications, Economics and Sociology, Vol. 8, No 1, pp. 88-"Licznik" na stronie 105.

DOI: $10.14254 / 2071-789 X .2015 / 8-1 / 7$

\title{
FORMATION OF ORGANISATIO- NAL KNOWLEDGE IN UKRAINIAN ENTERPRISES ON THE BASIS OF INTERNAL COMMUNICATIONS
}

\begin{abstract}
This paper presents the results of theoretical research regarding issues related to the formation of organisational knowledge at modern enterprises. This organisational knowledge has some peculiarities, as discussed in the paper. The emergence of organisational knowledge and its collective character is determined in many ways by internal communications.

The main purpose of the research is to identify types of internal communication strategies as a basis of organisational knowledge formation at enterprises.

Four types of enterprise internal communication strategies defining the peculiarities of exchange and spread of knowledge among employees are set out: the supporting formally-documentary internal communication strategy, the network information-technological internal communication strategy, the engaging socially oriented internal communication strategy and the integrative knowledge-producing internal communication strategy.
\end{abstract}

The research results confirmed that there are different approaches to defining the factors contributing to knowledge sharing. When working out measures to manage internal organisational communications at enterprises it is reasonable to single out two aspects: socio-psychological and informational-technological. The author suggests management arrangements to provide the transition from other types of internal communication strategies to the integrative knowledge-producing strategy.

Keywords: socio-psychological and information-technological aspects of internal communications, Ukraine, knowledge sharing, internal communication strategies, organisational knowledge of enterprises.

JEL classification: J24, M53

\section{Introduction}

Modern scientists researching in the sphere of socio-economic processes assert that the most acceptable present-day model of development for many countries is the society of knowledge that has a knowledge economy as its significant part.

Today we have a number of key indicators which reflect the level of development of knowledge economies. One of them is the Knowledge Economy Index (KEI), according to which Ukraine occupies the $56^{\text {th }}$ place in the list of 146 countries involved in the research (The World Bank Group, 2013). Ukraine's position in the world rating shows the necessity of search- 
ing out effective ways to develop a knowledge economy. First of all it is advisable to define 'knowledge economy', or 'knowledge-based economy'. According to the OECD $(1996, \mathrm{p} .7)$ 'knowledge-based economies' are those 'economies which are directly based on the production, distribution and use of knowledge and information', and in which knowledge distribution through formal and informal networks is very essential to economic performance. Dzunic, Boljanovic and Subotic (2012, p. 302) note that the transition to a knowledge economy depends on people who can effectively and efficiently manage knowledge; who can create, keep, share and combine knowledge in organisations; integrate knowledge in products and services and do all this faster than their competitors. All these processes take place in organizations and at enterprises. Brinkley (2008) says that enterprises, as core economic actors, play the decisive role in the development of a knowledge economy. Taking this into account it is possible to say that the introduction of knowledge formation and management technologies into the practical activities of enterprises and organisations will contribute to the active transition of Ukraine to the model of knowledge economy.

This paper is focused on the formation of organisational knowledge at the enterprise level. The basic differences of organisational knowledge from individual knowledge are its collective character and involvement in the business processes of an organisation. The majority of researchers emphasized these differences as key. The involvement of organisational knowledge in business processes determines the basic sense and purpose of this knowledge. In the opinion of Husted and Michailova (2002, p. 62), 'to become profitable knowledge management should suggest not the accumulation of knowledge but its integration'. For the term 'integration' we understand not only the involvement of knowledge in the business processes of organisation, but its interconnection and consolidation in the integrated system. From the point of view of Hodgkinson and Sparrow (2002, p. 105) 'only the distribution of local knowledge makes it organisational'. Thus, the integration and distribution of individual knowledge ensures its collective character, made possible by the basis of processes of sharing in the organisation.

This paper presents the theoretical research and pays primary attention to such aspects of the formation of organizational knowledge as knowledge sharing and internal communications. From the point of view of Ragusa (2010) these two aspects are positively associated. Kalla (2005) views knowledge sharing as a function of integrated internal communications. The connection between internal communications and the intensity of knowledge sharing is studied by Taylor and Zorn (2004). Analysis of different authors' approaches to the definition of the essence of internal communications in organizations leads to conclusions regarding these communications' connection with the processes of knowledge sharing between employees. These processes are important components of the formation of organizational knowledge.

Study of the literature devoted to the factors of impact on knowledge sharing in organisations made it possible to distinguish two groups of such factors: socio-psychological and information-technological. The results of empirical researches of different authors, presented below, demonstrate the connections between these factors and internal communications within organisations. This analysis was the basis for choosing active/poor use of socio-psychological and information and communication technologies of knowledge sharing as the distinguishing feature which characterises different approaches to internal communications at enterprises. As Hola (2012) says, communication strategies should be based on company strategy as a means for its fulfilment.

The main contribution of this research into the development of the theory of internal communications and knowledge management is the author's theoretical approach to the classification of internal communication strategies (ICS). This classification suggests taking into account the purpose of each strategy and the preferred channels of knowledge transmission 
typical for the enterprise's corporate culture. It makes possible the integration of any type of ICS with the general strategy of the enterprise.

The purpose of the given research is the identification of the types of internal communication strategies as a basis for the formation of organisational knowledge at enterprises.

\section{Methodology}

In conformity with the theoretical character of the research the author has chosen such methods as theoretical analysis, generalisation, induction and logical methods. The method of theoretical analysis was used to study the scientific papers devoted to the definition of the essence of internal communications in organisations, factors influencing knowledge sharing between employees. As a result of the generalisation of empirical researches made by the contemporary scientists, two key aspects of internal communications in organisations are presented. The induction method allowed the combination of such elements of ICS as the purpose of communication, the preferable means of communication and the type of corporate culture and to formulate the characteristics of the four types of ICS. The logical method was used to justify the list of management arrangements contributing to transition to integrative knowledge-producing ICS from other types of ICS.

\section{The concepts of organisational knowledge and internal communications}

Knowledge in organisations, in the opinion of Zhuravlev and Nestik (2009, p. 4), has a 'socio-psychological nature as it includes not only information and personality meanings but elements of group consciousness. More often than not knowledge is formed in joint activity and includes cognitive and emotional components of group attitude to reality'. In view of these authors, the theory of distributed cognition is important to explain the nature of organisational knowledge with the purpose of its further management. Hutchins is considered to be the founder of this theory. He claimed that when solving complex multicomponent tasks requiring the whole range of diverse knowledge, cognitive processes are distributed between various people in such a way that together they solve a problem which can't be solved by each of them individually (Hutchins, 1995).

Many cognitive processes are distributed with the help of external aids or artefacts. Thus, distributed cognition becomes possible thanks to the joint work of human intellect and material carriers of knowledge (the role of which can be played by, for example, software and databases). The process of knowledge distribution among enterprise employees solving common tasks determines the collective nature of organisational knowledge. In Gibson's (2001, p. 123) opinion, 'collective cognition does not reside in the individuals taken separately, though each individual contributes to it. Nor does it reside outside them. It is present in the interrelations between the activities of group members'. Ushakov (2003) believes that collective knowledge is the intercommunication of individual knowledge, its dialogue but not necessarily its identity. The emergence of organisational knowledge and its collective character is determined in many ways by active interaction between employees.

The phenomenon of 'transactive memory' or 'transactive knowledge' testifies in favour of this statement. Wegner $(1987$, p. 186) reveals the essence of a transactive memory system as a 'set of individual memory systems in combination with the communication that takes place between individuals'. Wegner suggests that the name for this sort of knowledge is 'organisational metaknowledge', which is the knowledge of employees and executives about the ways 
this or that knowledge and necessary information is distributed within the enterprise, i.e. the specific carriers with which they are connected.

The majority of researchers stick to the opinion that organisational knowledge has an informational nature, i.e. it is the result of recognition, processing, transformation, interpretation of information and its practical application. At the same time, there is a point of view that

it is not the information by itself which is the mover of the development of society but the ways of its use. In this connection it is reasonable to shift the scientific accents from information to communicating knowledge, to the systems of interaction by way of information exchange and their transformation into competitive advantages since the information systems are based on intraorganisational and inter-organisational interactions, i.e. systems of communications (Krivokora, 2008, p.1).

'Information alone is not enough. The existence and efficient activity of organisation is ensured only when information is transformed and processed, i.e. when communicative connections emerge' (Zihert, 1990, p. 20).

The foregoing allows us to conclude that formation and management of organisational knowledge are based on effective organisational communications. It is important to underscore that there are two basic directions of organisational communications: internal and external communications. External communications ensure the interaction of an enterprise with its external environment. This article gives special consideration to internal organisational communications. Table 1 gives the definitions of internal communications.

Table 1. The concept of internal organisational communications

\begin{tabular}{lc}
\hline \multicolumn{1}{c}{ Definition } & Author \\
\hline $\begin{array}{l}\text { Message transfer by formal and informal channels in relatively large } \\
\text { group of people which results in creation of meanings which have an } \\
\text { influence on members of the team and organisation as a whole. }\end{array}$ & Yakovlev (2006) \\
$\begin{array}{l}\text { Social practice, part of social process which in the course of time } \\
\text { produces, reproduces and modifies specific styles of communication. }\end{array}$ & Zachry (2005) \\
\hline
\end{tabular}

The whole set of information-institutional ways of interaction of subject and object of management which are determined by the laws of organisation functioning directed at accomplishment of the objectives

Bondarenko (2012) of its mission.

The strategic management of interactions and relationships between stakeholders within organisations across a number of interrelated dimensions including internal line manager communication, internal team communication, internal peer project communication and interWelch and Jackson (2007) nal corporate communication.

Communication within an organisation... a lot more than people talking to one another, however. It's the life blood of any organisation, the way in which everyone gets the information.

Community Tool Box

Such a process, in which an organisation shares its information, builds commitments and manages the changes.

All formal and informal communication taking place internally at all levels of an organisation.

Bevan and Bailey (1991)

Source: author's compilation based on the theoretical analysis of scientific publications

In generalizing these definitions it may be noted that efficient internal communications ensure efficient interaction between employees that, in its turn, stimulates efficient exchange of knowledge within the organisation. 
Some key principles of effective internal communications were suggested by Finch, Hansen and Alexander (2010). These include the observation that internal communications consist of accurate, consistent, and timely information; that communications never stop and present a continuous interactive process; that internal communications are always two-way communications and are meant to help inform decision making and influence employee behaviour in ways that benefit government, the public, and the employees themselves.

In the opinion of Tariszka-Semegine (2012) the complete or partial lack of internal communication presupposes the following negative effects: losing confidence in managers; a low level of identification; a high level of fluctuation; and the spread of informal communication (gossip).

As Rutanen (2013, p. 16) and Juholin (2009, p. 30) say, 'internal communication in organisations supports their daily functions. This type of "everyday communication" is the most important form of communication in all organisations. Internal communication supports and enables daily working by producing guidelines for processes and codes of conduct'.

We can single out the support of sharing and distribution of organisational knowledge from the important functions of internal organisational communications. The famous works by Nonaka and Toyama (2003, p. 4), devoted to the study of companies creating knowledge, note that 'knowledge creation starts with Socialization, which is the process of converting new tacit knowledge through shared experiences in day-to-day social interaction'. The committed management of organisational communications will contribute to the formation of organisational knowledge. It is not a sum of individual knowledge but an aggregate of knowledge of a higher level based on the existence of metaknowledge and causing synergetic effects. From the point of view of Surovtseva (2008, p. 126), 'the main requirement and criterion of efficiency of management of organisational communications is strict orientation at strategic objectives of organisation and how much communication activities brought an organisation nearer to these objectives'.

\section{Contribution of internal communications to knowledge sharing}

When working out measures to manage internal organisational communications at modern Ukrainian enterprises, it is reasonable to single out two aspects of these communications: socio-psychological and informational-technological.

The study of the socio-psychological factors which stimulate and block the exchange of knowledge among employees is significant within the framework of the socio-psychological aspect of communications management as an element of knowledge management. Factors stimulating knowledge sharing between employees were studied by various scientists (Table 2).

Table 2. Approaches to definition of factors contributing to knowledge sharing

\begin{tabular}{|c|c|}
\hline $\begin{array}{l}\text { Factors contributing to knowledge sharing } \\
\text { between employees }\end{array}$ & Author \\
\hline 1 & 2 \\
\hline Motivation, support, trust. & Bukowitz and Williams (2000) \\
\hline $\begin{array}{l}\text { Individual (enjoyment in helping others, knowledge self } \\
\text { efficiency) and organisational (management support, } \\
\text { organisational reward). }\end{array}$ & $\begin{array}{l}\text { Lin, 2007; Rahab, Sulistyandari and } \\
\text { Sudjono (2011) }\end{array}$ \\
\hline $\begin{array}{l}\text { Open leadership climate, customer-focused vision for } \\
\text { change, performance orientation, learning and reflection, } \\
\text { information quality, satisfaction with change processes. }\end{array}$ & Taylor and Wright (2004) \\
\hline
\end{tabular}


RECENT ISSUES IN ECONOMIC DEVELOPMENT

\begin{tabular}{lc}
\hline \multicolumn{1}{c}{1} & 2 \\
\hline Meaningfulness and voice. & MacLeod and Clarke (2009) \\
\hline Interpersonal trust. & Levin, Cross, Abrams and Lesser (2003) \\
\hline $\begin{array}{l}\text { Connection with firm efficiency and security and moti- } \\
\text { vation of the employees. }\end{array}$ & Kalla (2005) \\
\hline
\end{tabular}

Environmental factors (organisational context, interper-

sonal and team characteristics, cultural characteristics) and motivational factors (beliefs of knowledge owner-

Wang and Noe (2010)

ship, perceived benefits and costs, justice).

\begin{tabular}{lc}
\hline Social, managerial, organisational, technical. & Smith and McKeen (2002) \\
\hline Trust, group and organisational factors. & Zhuravlev and Nestik (2009) \\
\hline $\begin{array}{l}\text { Individual factors: standardized form of thinking, } \\
\begin{array}{l}\text { conformism, orientation at external authority, feeling of } \\
\text { attachment to the group, security. }\end{array}\end{array}$ & Andreeva (2007) \\
\hline
\end{tabular}

Organisational factors: technological infrastructure as a

basis of effective communications, organisational culture contributing to sharing of knowledge from one employee

Rumyantzeva (2009)

to another, continuous training of personnel.

Motivation of the person who shares his knowledge, experience; type of knowledge and form of its sharing; mutual roles which connect the participants of communi-

Kirilkina (2011)

cative interaction; common context.

Source: author's compilation based on the theoretical analysis of scientific publications

Empirical data of some research presented in Table 2 show the impact of socio-psychological factors on knowledge sharing. Zhuravlev and Nestik (2009) proved that there was a positive correlation $(\mathrm{r}=0,549, \mathrm{p}<0,001)$ between the level of trust in the organisation and the readiness of employees to engage in knowledge sharing. These authors noted that there were links between a person's readiness to knowledge sharing and his or her value orientations. The great role of trust in the process of knowledge sharing was mentioned by Bukowitz and Williams (2000) and Levin, Cross, Abrams and Lesser (2003).

In its turn, trust is closely connected with effective internal communications, as demonstrated by the works of Allert and Chatterjee (1997), Ruppel and Harrington (2000) and Zeffane (2011). Motivation as a factor influencing knowledge sharing is recognised by such authors as Bukowitz and Williams (2000), Kalla (2005), Wang and Noe (2010), Kirilkina (2011). O'Donovan (2009) offers empirical data on the links between communications and motivation of employees: $91 \%$ of business leaders who feel they do not clearly communicate with their employees agreed that they had perceived a drop in employee motivation. These data confirm the connection of internal communications with employees' motivation and stimulation of knowledge sharing. On the basis of these findings we can make a theoretical presupposition that factors which contribute to knowledge sharing are closely connected with internal communications.

It is worth noting that the factors and terms influencing knowledge sharing listed in Table 2 mainly reflect the socio-psychological aspect of internal communications management. The application of information and communication technologies at enterprises gives a number of significant advantages in the process of internal communications management as well. These advantages were proved by the research of company GFK Ukraine (Virtual press-centre 'Microsoft-Ukraine', 2012). Among the advantages formed when delivering personal information to employees via information and communication technologies (instead of arranging personal meetings and conferences) the most often mentioned are as follows: veracity of information; high speed of information delivery; possibility of personalized address to everyone; possibility 
of personal feedback; personal information confidentiality preservation; production personnel management processes automation; personnel department time and consumables (corporate publications print etc.) costs saving (Virtual press-centre 'Microsoft-Ukraine', 2012). In spite of the availability of such advantages, modern Ukrainian enterprises are not using all of them in the process of internal communications.

According to the results of the same study by GFK Ukraine, the most frequently used channels of delivery of personal information to enterprise employees in 2012 were as follows: through the supervisor, at the meeting of employees and meetings with top leadership, information stands and notices (Virtual press-centre 'Microsoft-Ukraine', 2012). Medzhybovska (2012) made a comparative analysis of the availability of websites and the frequency of use of different means of communication by Ukrainian enterprises of two groups (industrial enterprises and all other enterprises). This author's empirical data showed that both groups of enterprises used mostly telephone, e-mail and postal mail. The frequency of each method's use is different. The telephone is used in $40 \%$ of cases of communications by industrial enterprises and in $95 \%$ of cases by other enterprises. E-mail is used by industrial enterprises in $35 \%$ of cases of communications. Other enterprises use it in $85 \%$ of cases. Postal mail is used in $35 \%$ of cases by industrial enterprises and in $50 \%$ by other enterprises.

These studies are particularly interesting in comparison with similar studies made in other countries. According to Miller (2012), 55\% of internal communication practitioners in the U.K. believe that they are expected to 'have a good understanding' of social media and an $33 \%$ felt they are expected to 'know all about' social media. However, a pilot study in Europe suggests that 'digital native' (a generation born during or after introduction of digital technologies, during 1980s or after (Prensky, 2001)) employees still prefer more traditional channels, such as e-mail newsletters, intranet news, and employee meetings (Friedl and Vercic, 2011). Another article (Newsweaver, 2014) was devoted to the use of internal communications at enterprises. The results of this research show that the most frequently used means of communication are such channels as the intranet (93\%), e-mail (90\%) and leadership communications (84\%); 68\% of respondents can communicate via e-mail with at least $80 \%$ of their employees.

The well-established situation at Ukrainian enterprises requires a serious review of existing approaches to internal communications. The processes of formation of organisational knowledge as the sum total of individual knowledge of employees and also information and knowledge stored in non-personified data carriers (in digital databases, instructions, project documentation etc.) directly depend on internal organisational communications.

\section{Internal communication strategies}

As mentioned above, internal communications play an important role in knowledge sharing among employees. A systematic and clear process of organisation of internal communications at an enterprise is a basis for the formation of its organisational knowledge. The author suggests four types of international communications strategies (ICS) for an enterprise. It is advisable to choose as the key feature of classification active/poor use of socio-psychological and information and communication technologies at enterprise. These two aspects significantly define the peculiarities of exchange and spread of knowledge among employees.

The separation of varieties of enterprise ICS demonstrates the peculiarities of the exchange and spread of knowledge among employees. It will help to systematize and make clear the processes of organizational internal communications management. 
Therefore, we can present in the graphic form the four types of ICS depending on intensity of the use of information and communication and socio-psychological technologies ensuring the exchange and transmission of information and knowledge between employees (Fig.1).

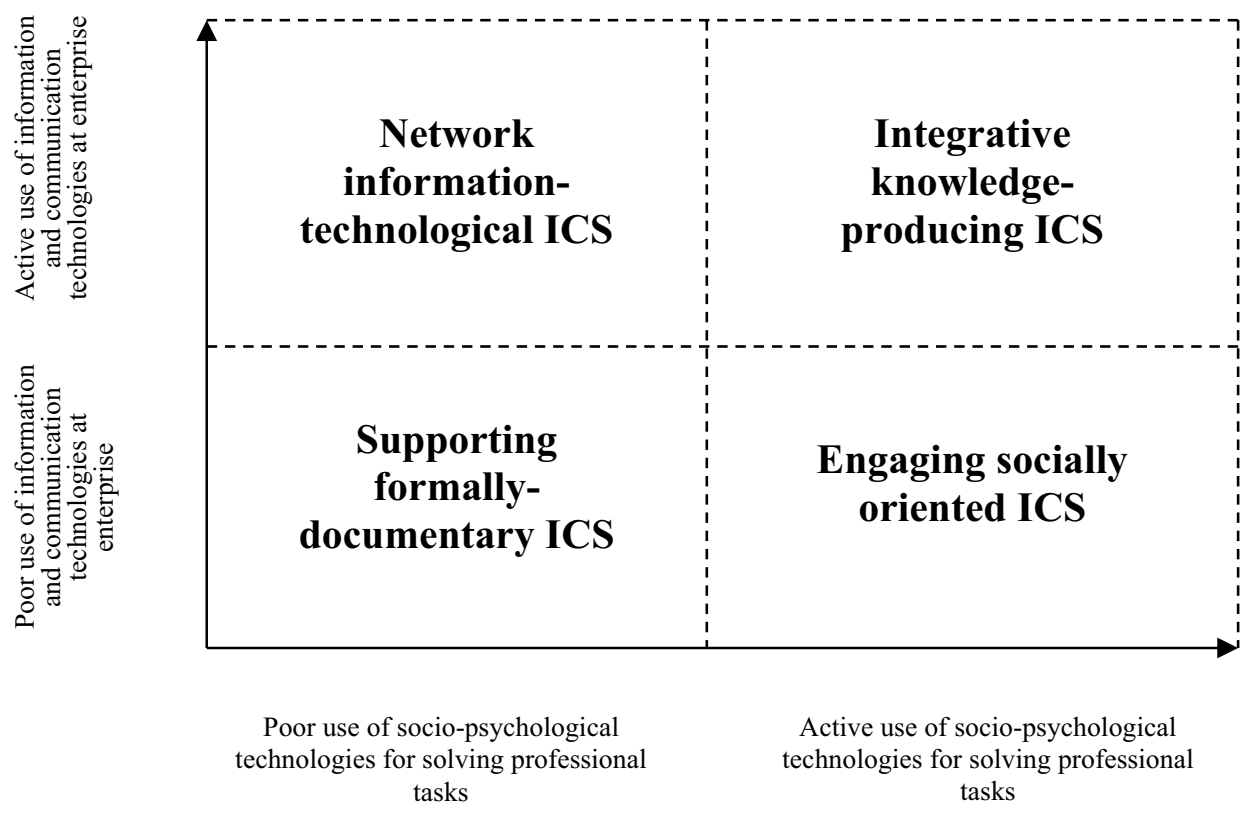

Fig. 1. Types of ICS

Source: elaborated by the author.

Each strategy is characterized by definite peculiarities and conditions which ensure the expediency of its use. Among basic peculiarities defining ICS at enterprises, it is useful to analyse the preferred channels and means of information and knowledge transmission typical for the enterprise corporate culture and basic objective of realization of this or that strategy.

It should be noted that certain elements are interrelated. For example, the targets of ICS, set by the management, will define the choice of channels and means of communication and accord with the basic strategic objectives of organisation development. These objectives, in turn, are in close interrelation with the corresponding types of corporate culture.

The close connection between the types of corporate culture and internal communications is emphasized by Johnes (2013), the communications expert, who holds the opinion that

the role of internal communications is not about narratives; in fact, it's not about messages at all. The starting point is to decide what sort of business you want and what types of behaviours are needed to support them. So if the business wants a culture that is open, honest, non-hierarchical, meritocratic, collaborative, curious and empowered, then the role of internal communications is to provide a rich communication environment in which those values can flourish.

Let's consider at greater length the mentioned types of ICS. The purpose of the supporting formally-documentary ICS, as a rule, is not to manage the development of organisational knowledge but, most likely, is intended to preserve and use that knowledge. In this system, traditional formal channels and informal unstructured 'from mouth to mouth' channels of knowledge transfer between employees prevail. These channels are closely connected with an organisational structure of an enterprise and the system of circulation of documents. 
According to the European Committee for Standardization (2004), organisational culture with this approach to internal communications is called 'traditional' with the following characteristics:

- limited information distribution;

- many management levels;

- uneven responsibility;

- rules based, formal structure;

- risk adverse;

- occasional training policy;

- more financial focus;

- knowledge retention;

- low emotional intelligence and cultural awareness.

When oriented at the active use of the information-technological component as a basis of internal communications, primary attention is given to the creation, accumulation and development of digital carriers of knowledge and information. In this case, network information-technological ICS is used. The main objective of this strategy is the accumulation and increase of the structural intellectual capital of an enterprise. Correspondingly, digital channels are going to be the preferred channels of information transfer. Their main advantages are the high speed of information transfer and the possibility of overcoming space limitations. Their shortcomings are the levelling of the emotional component of communication and the absence of direct transfer of tacit knowledge from experts to other employees.

The network information-technological ICS can be realized in the effective way at the enterprises with the type of organisational culture called 'WEB-culture'. When referring to the WEB-culture of an organisation Ilyashenko (2013, p. 33) suggests we should see

the whole scope of knowledge, skills, experience, beliefs, peculiarities of behavior and interrelations of personnel, motivation of their behavior, organisation of activity and management which define the character and degree of perception by individual members of the staff, departments, organisation of Internet technologies (WEB-technologies) on the whole, willingness and ability to use them effectively in various aspects of production-sale and other activity, move operations (in full or partially) into Web-space with the purpose of deriving economic or other benefit.

Isopeskul (2008) suggests the consideration of four levels of WEB-culture (process level, level of cults, level of operations and reflexes and superficial level), within the framework of a so-called 'electronic nerve system' of an organisation, by which we mean the total set of information-communication technologies ensuring the exchange of knowledge between the employees, storing information in digital repositories etc. Two authors (Isopeskul, 2008; Illiashenko, 2014) studied the peculiarities of organisational WEB-culture. They suggested the following characteristics of WEB-culture:

- support of the development of organisational intellect at enterprises;

- active knowledge sharing and its production on the basis of information communication technologies;

- high rate and availability of transmission of information in organization and its truth;

- leading role of the system of coordination of the employees links between which are formed in spite of the position in the organizational hierarchy;

- organisation of many types of work, which include creation and administration of personal sites, web-pages, social networks, maintenance of databases containing information, relating to the work performed. 
Thus, taking into account the objectives and peculiarities of the network information-technological ICS, it may be noted that its use will be advisable at those enterprises where:

- the problem with the psychological barriers and personnel qualification in the sphere of information technologies has been solved (existence of psychological resistance to the active use of information technologies or lack of qualification for the work with certain software will make impossible realisation of this strategy);

- communications on the basis of information technologies promote the increase of primary activity efficiency (if the organization of internal communication on the basis of information technologies provides extra and not effective use of working time of employees, this strategy will secure decrease of productivity);

- information security problem has been solved (application of this strategy at enterprises with ongoing information security problems is inappropriate);

- there is a network of physical branches located at significant distances from one another.

The purpose of engaging socially-oriented ICS based on the formation of organisational knowledge as a result of the direct social interaction between enterprise employees lies in the formation and development of human intellectual capital. Personal, professional contacts and meetings or other events dedicated to the discussion of professionally important topics, such as seminars, conferences, symposiums and various organisational methods of training, both collective (trainings, for example) and individual (tutorship, coaching) are the basic channels and means of exchange and distribution of information and knowledge under engaging socially-oriented ICS.

The characteristic features of an organisational culture capable of creating the necessary context for the successful realization of this internal communication strategy to a large extent have something in common with the cultures of professional communities or communities of practice. According to Marinicheva (2008, p. 280), a

community of practice is the self-organizing informal group of people united by professional interests and exchanging the knowledge on specified subject area. They communicate to solve professional problems together, learn from each other and find new solutions and approaches. There is a common approach that communities of practitioners are formed and they work within the organisation.

According to Wenger (2006) there are three crucial characteristics of communities of practice: the domain (the members of community are connected by common interests); the community (building relationships enables the members of community to learn from each other); and the practice (the members of community develop a shared repertoire of resources for their practice). Other authors studying the characteristics of communities of practice provide the following list:

- solely voluntary participation of the members of professional communities in their activity;

- lack of connection of communities with formal structure of enterprise (Ivanov and Karlukova, 2012);

- forming around leaders-experts but not formal managers or supervisors;

- active participation of community members in setting and adopting their own goals (not thrust upon them by from outside);

- solution of tasks important for a company;

- prolonged time of existence supported until members of community recognize its importance and significance (Marinicheva, 2008); 
- exchange with not only explicit, but significant volumes of implicit, knowledge and specific experience of problem solution;

- more open than in formal groups to the exchange of knowledge, confidential relations, absence of fear of making a mistake (Andrusenko, 2006).

This list of characteristics of communities of practice is not exhaustive, but it describes them and shows their distinctive features from other groups and unions of enterprise employees. Communities of practice shouldn't be identified with network communities. Information and communication technologies may play an auxiliary role of additional channels of information exchange in communities of practice, but direct social interaction between professionals is nonetheless of paramount importance. According to Andrusenko (2006) the individual is the fundamental unit of community, making clear the real difficulty and importance of building and organising the work of a community as powerful social network of connections.

These characteristics of professional communities correspondingly reflect the peculiarities of an organisational culture which will contribute to the effective work of such communities. These peculiarities include:

- determination of influence and competence of enterprise employees on the basis of their professionalism and not their formal positions;

- free exchange of knowledge within groups of professionals but, at the same time, the presence of barriers for those employees who are not members of such groups;

- efficient circulation of implicit knowledge and its transformation into human intellectual capital;

- high level of internal motivation of activity, caused by the voluntary participation of employees in communities, prevalence of orientation at professional development and moral satisfaction with joint effective work;

- orientation at search of new approaches to problem solution, stimulation of innovational ideas and propositions;

- encouragement of all forms of professional training with the emphasis on those which offer direct interaction between participants of educational process both in the case of group (e.g., trainings) and individual (e.g., tutorship) types of learning.

Integrative knowledge-producing ICS, which is the combination of two previous approaches, offers active exchange between employees, participants of professional communities, but also those who are outside them. Active use of information communication technologies serve as additional instruments of this exchange. Its main purpose is the formation of both human and structural intellectual capital and the sum-total of intellectual assets of enterprise ensuring its competitive advantages at present and future period. A culture based on knowledge (or knowledge culture) is the corporate culture, which forms the basis for successful realization of the integrative knowledge-producing ICS.

The knowledge culture is the definite corporate philosophy which includes basic principles and values of the company corresponding to the strategic objectives, priorities, strategy of knowledge management which is the guideline for their operations and which is shared by all company employees (Smirnova and Voskresenskaya, 2008, p. 102).

Hendriks (2004, p. 2), considering various approaches to the study of knowledge culture (knowledge sharing culture, knowledge-centered culture, knowledge-friendly culture), emphasizes that 'such concepts refer to a culture of openness and trust, a culture in which learning is appreciated and in which experience, expertise and knowledge are considered more important than hierarchy'.

European experts attribute the following distinctive feature to the peculiarities of knowledge culture: wide information distribution, few management levels, shared responsibility, 
principles based, informal structure, the ability to take some risks, continuous learning policy, multifunctional focus, open, knowledge sharing and utilization, welcoming influences on organisational culture from the networks in which an organisation participates (European Committee for Standardization, 2004).

DeLong and Fahey (2000) singled out four basic characteristics of organisational cultures contributing to effective creation and integration of new knowledge at an enterprise:

- viewing incoming knowledge as the starting and not final point of innovations;

- encouragement of discussions of key strategically significant problems with the use of external and internal sources of knowledge;

- high level of participation of employees in the processes of search, discussion and synthesis of knowledge included into business processes;

- continual review and correction of successful in the past beliefs and assumptions.

- Aksenova (2012) offers to view four basic elements of organisational culture oriented at production of new organisational knowledge: interaction, involvement, adaptability and vision of the future.

Active use of information and communication technologies as a basis of realization of all the conditions of a knowledge-based organisational culture contribute to the intensification of innovational processes at enterprise. The type of organisational culture within the framework of which the integrative knowledge-producing ICS is realized has the following characteristic features:

- orientation of enterprise employees not only at the consumption of available organisational knowledge but at the creation of new knowledge and its active exchange;

- understanding by employees and executives of the processes which underlie the creation of key organisational competences and connect them with organisational knowledge;

- a positive attitude and willingness of employees to accept organisational changes stipulated by the prioritization of innovative approaches to reaching the production targets and tolerance of mistakes made in conditions of continuous training and development;

- a high level of commitment of employees to working group and organisation as a whole, their participation in the processes of goal-setting at the enterprise;

- active use of information-communication technologies as a basic platform for knowledge exchange, including social software, artificial intelligence systems, workgroup support systems, holding teleconferences etc.

Characteristics of the above mentioned types of ICS are given in Table 3.

Table 3. Characteristic of types of ICS of enterprises

\begin{tabular}{llcl}
\hline \multirow{2}{*}{ Type of ICS } & \multicolumn{3}{c}{ Distinctive features } \\
\cline { 2 - 4 } & $\begin{array}{l}\text { Preferred channels and means } \\
\text { of information and knowledge } \\
\text { transfer }\end{array}$ & $\begin{array}{c}\text { Characteristic corporate } \\
\text { culture }\end{array}$ & $\begin{array}{l}\text { Main objective of in- } \\
\text { formation and knowl- } \\
\text { edge exchange }\end{array}$ \\
\hline \multicolumn{1}{c}{$\begin{array}{c}\text { Supporting } \\
\text { formally-docu- } \\
\text { mentary }\end{array}$} & $\begin{array}{l}\text { Traditional: formal ones - based } \\
\text { on documented orders and in- } \\
\text { structions, informal - based on } \\
\text { oral and not always structured } \\
\text { advice of colleagues, directed } \\
\text { mainly downward according to } \\
\text { hierarchy }\end{array}$ & 3 & $\begin{array}{l}\text { Formation of stan- } \\
\text { dard set of docu- } \\
\text { ments necessary for } \\
\text { enterprise function- } \\
\text { ing and strict regu- } \\
\text { lation of employees' } \\
\text { actions }\end{array}$ \\
\hline
\end{tabular}




\begin{tabular}{|c|c|c|c|}
\hline 1 & 2 & 3 & 4 \\
\hline $\begin{array}{l}\text { Network infor- } \\
\text { mation-techno- } \\
\text { logical }\end{array}$ & $\begin{array}{l}\text { Digital based on modern infor- } \\
\text { mation technologies including } \\
\text { specialized Internet sites, forums } \\
\text { etc. } \\
\text { Weak emotional component or its } \\
\text { absence. }\end{array}$ & WEB-culture & $\begin{array}{l}\text { Formation of struc- } \\
\text { tural intellectual } \\
\text { capital }\end{array}$ \\
\hline $\begin{array}{l}\text { Engaging social- } \\
\text { ly-oriented }\end{array}$ & $\begin{array}{l}\text { Based on the use of professional } \\
\text { standards including participation } \\
\text { in specialized seminars, confer- } \\
\text { ences and other events intended } \\
\text { for face-to-face communication. } \\
\text { Rich emotional gamma. }\end{array}$ & $\begin{array}{l}\text { Culture of professional } \\
\text { communities } \\
\text { (communities of prac- } \\
\text { tice) }\end{array}$ & $\begin{array}{l}\text { Formation and pres- } \\
\text { ervation of intellectu- } \\
\text { al capital }\end{array}$ \\
\hline $\begin{array}{l}\text { Integrative } \\
\text { knowledge-pro- } \\
\text { ducing }\end{array}$ & $\begin{array}{l}\text { Combined, based on active } \\
\text { direct interpersonal interaction } \\
\text { of employees and both social } \\
\text { and information-communication } \\
\text { technologies are used to raise the } \\
\text { efficiency and accessibility of } \\
\text { this interaction. }\end{array}$ & $\begin{array}{l}\text { Innovation-oriented } \\
\text { organisational culture } \\
\text { based on knowledge }\end{array}$ & $\begin{array}{l}\text { Formation of both } \\
\text { types of intellectual } \\
\text { capital and intellectu- } \\
\text { al assets of enterprise }\end{array}$ \\
\hline
\end{tabular}

Source: elaborated by the author.

\section{Integrative knowledge-producing ICS as a basis of the formation of organisational knowledge}

Taking into account the characteristics of each of ICS described in Table 3 it is necessary to note that integrative knowledge-producing ICS is desirable for enterprises functioning in the society of knowledge. This strategy is a basis of formation of organisational knowledge at enterprise. Transition to this ICS may be realized by enterprises adhering to the traditional, network, information-technological and engaging socially-oriented ICS. However, management technologies contributing to the accomplishment of the mentioned variants of transition will differ depending on which of three strategies is currently the first priority at the enterprise.

Table 4 lists the variants of enterprise transition to integrative knowledge-producing ICS and the efficient technologies of management contributing to the realization of this transition.

Before considering managerial influences contributing to the transition from one ICS to another it is necessary to emphasize that such transitions are reasonable in those cases featuring a change in the conditions of enterprise operations, its mission, or its strategic plans.

The transition from network information-technological ICS to integrative knowledge-producing ICS suggests that, besides active interaction with information technologies, employees must learn to interact with each other, simultaneously exchanging knowledge and information. The main task of this transition is turned to the expansion of the already implemented information-technological possibilities at the expense of additional development of the socio-psychological aspect of interaction between employees. At the same time, it is very important that leading specialists in any sphere of activity of the enterprise must demonstrate their grasp of information technologies with the purpose of determining whether they are active users of the corporate net. Planning, organisation and holding of trainings and seminars and coaching, tutorship, buddying, mentorship and other forms of training of employees with the use of information and communication technologies available at the enterprise will allow the 
intensification of the processes of social interaction between employees. Stimulation of employees to create professionally oriented work groups interacting on the basis of common tasks, provision of bonuses for participation in such groups will create preconditions for the formation of more stable professional communities.

Table 4. Management arrangements contributing to transition to integrative knowledge-producing ICS

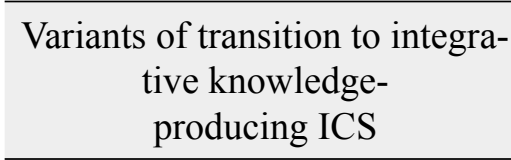

Basic management arrangements contributing to realization of transition

From network information tech- Identification of leading specialists, determination of their level nological ICS of knowledge of information technologies with the purpose of determination of the degree of their involvement in knowledge exchange in corporate net; planning and organisation of group training; holding of videoconferences, based not only on the use of IT but on the social interaction, stimulation of employees to creation of work groups, participation in communities of practitioners including intraorganisational ones

From engaging socially-orient- Informatization mainly at the expense of acquiring socially oriented ICS ed software, organisation of data flows, overcoming of psychological barriers faced by employees in connection with the necessity of mastering new technologies, training of employees for working with new software

From supporting formally-docu- Combination of all mentioned above arrangements mentary ICS

Source: elaborated by the author.

The transition from the engaging socially-oriented ICS to the integrative knowledge-producing ICS requires additional costs and efforts directed at informatization of the enterprise, correct organisation of information flows and overcoming of psychological barriers connected with the necessity of mastering new technologies by employees. The special role in this process is given to software which supports group work with information, including socio-oriented software. The probability of very active use of such software is high enough because it is able to support already-formed social links between professionals at an enterprise without upsetting the principles of interaction adopted by employees and moves this interaction to a more efficient level. Purchase and installation of the mentioned types of software must be based on a preliminary examination of the level of knowledge of information technologies by employees and their psychological readiness to use these technologies in their work. The organisation of training employees to work with this new software, including the use of financial incentives to start working with information and communication technologies for communication and interaction within their production targets, is very important.

The transition from the supporting formally-documentary ICS to the integrative knowledge-producing ICS is the most complex variant of transition among those presented. It can be realized both directly and consecutively, using one of the mentioned above strategies. The direct approach is preferable but at the same time more labour-intensive because it requires simultaneous realisation of both of the above-mentioned groups of measures. 


\section{Conclusions}

Ukraine's transition to the model of a knowledge-based economy requires essential changes at all economic levels. One way to undertake such changes is the improvement of the processes of formation, distribution and sharing of organisational knowledge which belong to key economic actors: enterprises. Organisational knowledge is of collective origin. It is formed due to active interaction and knowledge sharing between enterprise employees.

The theoretical analysis of the works of contemporary scientists made it possible to suggest conclusions about interferences and connections between the process of knowledge sharing and internal communications at enterprises. As a result, the author makes the conclusion that internal communications, being the instrument of knowledge sharing between employees, play an important role in formation of organisational knowledge.

On the basis of systematization of the factors of influence on knowledge sharing in organizations the author suggests a distinction between two aspects of internal communications: socio-psychological and information and technological. The main theoretical result of the research is the author's classification of ICS. This classification is made on the basis of active/poor use of socio-psychological and information and communication technologies in the process of knowledge sharing at enterprise. In conformity with this classification the author suggests the following four types of ICS:

- supporting formally-documentary;

- network information-technological;

- engaging socially oriented; and

- integrative knowledge-producing.

Each of the mentioned types of the strategies presupposes:

- the achievement of certain purpose of knowledge and information sharing connected with the general strategy of enterprise;

- the use of the existing at enterprise channels of information and knowledge transfer;

- integration with the corresponding type of corporate culture which creates certain preconditions for successful realization of one or other internal communication strategy.

The article suggests that the key role in formation of organisational knowledge belongs to integrative knowledge-producing ICS. In connection with this the author systemizes the groups of managerial arrangements contributing to transition of enterprises to the integrative knowledge-producing ICS from other types of ICS.

\section{References}

Abrams, L. C., Cross, R., Lesser, E. and Levin, D. Z. (2003), Nurturing interpersonal trust in knowledge-sharing networks. Academy of Management Executive, Vol. 17, No. 4, 64-77.

Aksenova, N. V. (2012), Organizacionno-kulturny kontecst upravleniya znanyami i trudovym potecialom. Tomsk: FGBOU VPO "Nationalnyi issledovatelsky Tomsky gosudarstvenniy universitet".

Allert, J., Chatterjee, S. (1997), Corporate communication and trust in leadership. Corporate Communications, 2 (1), 14-21.

Andreeva, T. V. (2007), Individualniye predpochteniya rabotnikov k sozdaniyu i obmenu znaniyamy: perviye rezultaty issledovaniya. Nauchniye doclady, № 4(R), StPb.: NII menegmenta StPbGU.

Andrusenko, T. (2006), Svobodnaya energiya predpriyatiya. Recourse document. Generalny Direktor, №8 // http://www/URL: http://www.investor.net.ua/ru/articles/256.html?SID),

Bevan, R., Bailey, J. (1991), Public Relations and Labor Matters. In Ph. Lesly (ed.) Lesley's Handbook of Public Relations and Communication (pp. 231-245), Chicago: Probus Pub. Co. 


\section{RECENT ISSUES IN ECONOMIC DEVELOPMENT}

Bondarenko, F. V. (2012), Socialno-psychologycheskiye regulyatory organizacionnoy kommunikacyi. Vestnik MGOU. Seriya "Psyhologycheskiye nauki”, № 2, 45 - 51.

Brinkley, I. (2008), Knowledge economy and enterprise. A knowledge economy working paper. London: The Work Foundation.

Bukovich, W., Williams, R. (2000), The knowledge management fieldbook. Prentice-Hall, Financial Times.

Community Tool Box (2012), Promoting Internal Communication, available from: http://ctb.ku.edu/en/ table-of-contents/leadership/effective-manager/internal-communication/main.

DeLong, D., Fahey, L. (2000), Diagnosing cultural barriers to knowledge management. The Academy of Management Executive, V.14, No. 4, 113-127.

Dzunic, M., Boljanovic, J. D., Subotic, J. (2012), The importance of concepts of knowledge management and learning organization in managing the knowledge - flow in organizations. Management, knowledge and learning. International conference paper, available from: http://www.issbs. si/press/ISBN/978-961-6813-10-5/papers/ML12_075.pdf.

European Guide to Good Practice in Knowledge Management. Part 2: Organisational Culture (2004), Brussels: European Committee for Standardization, available from: http://michel.grundstein. pagespersoorange.fr/References/CEN_Final_Publication_0403/CWA14924_02_2004_Mar.pdf.

Finch, K., Hansen, C. and Alexander, R. (2010), Internal Communications. It' not Rocket Science. Province of Nova Scotia: Crown copyright.

Friedl, J. and Vercic, A. T. (2011) Media preferences of digital natives' internal communication: a pilot study. Public Relations Review, Vol. 37, Issue 1, 84-86.

Gibson, C. B. (2001), From knowledge accumulation to accommodation: cycles of collective cognition in work groups. Journal of Organizational Behavior, 22, 121 - 134.

Hendriks, P. (2004), Assessing the role of culture in knowledge sharing. Recourse document. The Fifth European Conference on Organizational Knowledge, Learning, and Capabilities. University of Innsbruck, Austria, available from: http://www2.warwick.ac.uk/fac/soc/wbs/conf/olkc/archive/ oklc5/papers/.

Hodgkinson, G. P., Sparrow P. R. (2002), The competent organization: a psychological analysis of the strategic management process. Buckingham, Philadelphia: Open University Press.

Holá, J. (2012), Internal communication in the small and medium sized enterprises. E+M Ekonomie a Management, Vol. 15, Iss. 3, 32-45.

Husted, K., Michailova, S. (2002), Diagnosing and fighting knowledge-sharing hostility. Organizational Dynamics, 31(1), 60-73.

Hutchins, E. (1995), Cognition in the wild. Cambridge, MA: MIT Press.

Illiashenko, S. N., Shipulina, U. (2013), WEB-cultura kak sostavlyayushaya ustoychivogo razvitiya organizaciy. Ustoychivoe razvitiye, Vyp. 8, 32-36.

Illiashenko, S. N. (2014), Web-culture as a factor of company's competitiveness enhancement. Marketing i management innovatziy, №3, 121-129.

Isopeskul, O. Y. (2008), WEB-cultura organizaciy. Ekonomycheskii vestnik Rostovskogo gosudarstvennogo universiteta, T. 6, № 3-2, 82-85.

Ivanov, O., Karlukova, O. (2012), Professionalnye soobshestva v Rossii: kolichestvenniy analis. HR-portal, available from: http://www.hr-portal.ru/article/professionalnye-soobshchestva-v-rossii-kolichestvennyy-analiz.

Johns, T. (2013), Internal communications in 2013. Recourse document. Simply-communicate, available from: http://www.simply-communicate.com/news/internal-communications/ internal-communications-2013.

Juholin, E. (2009), Communicare!Viestintä strategiasta käytäntöön. Helsinki: Inforviestintä. 


\section{RECENT ISSUES IN ECONOMIC DEVELOPMENT}

Kalla, H. K. (2005), Integrated internal communications: a multidisciplinary perspective. Corporate Communications: An International Journal, Vol. 10, No. 4, 302-314.

Kirilkina, O. V. (2011), Socialniye factory peredachi znaniy I obmena znaniyamy na primere rossiyskoy biznes-organizaciy. Vestnik Samarskogo gosudarstvennogo universiteta, №7, 15-23.

Krivokora E. I. (2008), Kommunikacionnye istochniki organzacyonnogo razvitiya. Recourse document. Problemy sovremennoy economyci, №3(27), available from: http://www.m-economy.ru.

Lin, H-F. (2007), Knowledge sharing and firm innovation capability: an empirical study. International Journal of Manpower, Vol. 28, 315 - 332.

MacLeod, D., Clarke, N. (2009), Engaging for Success: Enhancing Performance Through Employee Engagement. A Report to Government. Department for Business Innovation and Skills, available from: http://www.engageforsuccess.org/wp-content/uploads/2012/09/file52215.pdf.

Marinicheva, M. K. (2008), Upravlenie znaniyami na 100\%: putevoditel dlya praktikov. Moskva: Alpina Biznes Books.

Medzhybovska, N.S. (2014), Електронний бізнес промислових підприємств: сучасний стан і напрямки вдосконалення. Economic Forum, 1, 140-145.

Miller, R. (2012), How internal comms pros use social media. All things IC, available from: http://www. allthingsic.com/how-internal-comms-pros-use-social-media-2/.

Newsweawer (2014), Internal communication and technology survey report 2014, available from: http:// cdn2.hubspot.net/hub/301060/file-544707668-pdf/Whitepapers_PDF/Survey_Report_Final.pd$\mathrm{f} ? \mathrm{t}=1427390327362$.

Nonaka, I., Toyama, R. (2003), The knowledge-creating theory revisited: knowledge creation as a synthesizing process. Knowledge Management Research \& Practice, 1, 2-10.

O'Donovan, D. Staff who understand reward are more motivated. Employee benefits, available from: http://www.employeebenefits.co.uk/resource-centre/research/staff-who-understand-reward-are-more-motivated/9400.article.

Organisation for Economic Co-operation and Development (1996), The knowledge-based economy, available from: http://www.oecd.org/sti/sci-tech/1913021.pdf.

Prensky, M. (2001), Digital natives, digital immigrants part 1. On the Horizon, 9(5), 3-6.

Ragusa, A. (2010), Internal communication management. Individual and organizational outcome. London: BookBoon.

Rahab, Sulistyandari, Sudjono (2011), The development of innovation capability of small medium enterprises through knowledge sharing process: an empirical study of Indonesian creative industry. International Journal of Business and Social Science, Vol. 2, No. 21, p 112-123.

Rumyantzeva, I. V. (2009), Upravleniye obmenom znaniyamy kak factor razvitiya sovremennyh organizaciy. Moskva: OPMT RAGS.

Ruppel, C., Harrington, S. (2000), The Relationship of Communication, Ethical Work Climate, and Trust to Commitment and Innovation. Journal of Business Ethics, 25(4), 313-328.

Rutanen, I. (2013), Developing knowledge management and internal communication through a virtual workspace. Case: Company X. Leppävaara: Laurea Leppävaara.

Smith, H. A., McKeen, J. D.(2002), Instilling a Knowledge Sharing Culture. Third European Conference on Organizational Knowledge, Learning, and Capabilities, available from: http://business. queensu.ca/kbe/docs/Smith- McKeen\%2003-11.pdf.

Smirnova, V., Voskresenskaya, U. (2008), Korporativnaya kultura - kluchevoy factor v upravlenii znaniyami. Problemy teotii i praktiki upravleniya, N 12, 102-107.

Surovtseva, E. S. (2008), Aktualnye problemy upravleniya organizacionnymi kommunikaciyamy. Vestnik TGU, 2(58), 125-128.

Tariszka-Semegine, E. (2012), Organizational internal communication as a means of improving efficiency. European Scientific Journal, Vol. 8, No.15, 86-96. 


\section{RECENT ISSUES IN ECONOMIC DEVELOPMENT}

Taylor, J., Zorn, T. Knowledge Management and/as Organizational Communication. Paper presented at the annual meeting of the International Communication Association, New Orleans Sheraton, New Orleans, LA, May 27, 2004, available from: http://www.allacademic.com/meta/p112428_ index.html.

Taylor, W. A., Wright, G. H. (2004), Modeling and Managing the Preconditions for Effective Knowledge Sharing. In M. Khosrow (ed.), Innovations through information technology (pp.9-12), Hershey, London: Idea Group Publishing.

The World Bank Group (2013), Knowledge for development, available from: http://info.worldbank.org/ etools/kam2/KAM_page5.asp.

Ushakov, V. (2003), Kollektivno-raspredelennoe znanie, available from: http://www.ushakov.org/.

Virtual press-centre "Microsoft-Ukraine" (2012), Major enterprises underestimate the potential of cloud technologies for internal communications, available from: http://microsoftua.wordpress. com/2012/09/27/gfk-research-on-cloud/.

Wang, S., Noe, R. A. (2010), Knowledge sharing: A review and directions for future research. Human Resource Management Review, 20, 115-131.

Wegner, D. M. (1987), Transactive memory: a contemporary analysis of the group mind. In G. Mullen and G. Geothals (ed.), Theories of group behavior (pp. 185-208), New-York: Springer-Verlag.

Welch, M., Jackson, P.R. (2007), Rethinking internal communication: a stakeholder approach. Corporate Communications: An International Journal, 12 (2), 177-198.

Wenger, E. (2007), Communities of practice. A brief introduction, available from: http://www.ewenger. com/theory/.

Yakovlev, I. P. (2006), Kluchi k obsheniy. Osnovy teorii kommunicaciy. StPb: Avalon, Azbuka-Klassika.

Zachry, M. (2005), Conceptualizing Communicative Practices in Organizations: Genre-based Research in Professional Communication. Business Communication Quarterly, Vol. 63/4, 95.

Zeffane, R. (2011), Communication, Commitment \& Trust: Exploring the Triad. International Journal of Business and Management, 6(6), 77-87.

Zhuravlev, A. L., Nestik T. A. (2009), Socialno-psyhologycheskie factory obmena znaniyami v organizacyi. Vysshee obrazovanye dlya XXI veka: VI mezdunarodnaya nauchnaya konferenciya (pp. 3-12), Moskva: Mosk. Gumanit. Universitet.

Zihert, V., Lang, L. (1990), Rukovodit bez konfliktov. Moskva: Ekonomyka. 